\title{
ANALISIS FAKTOR-FAKTOR YANG BERPENGARUH TERHADAP KEBIJAKAN DIVIDEN PERUSAHAAN MANUFAKTUR (Studi Empiris Pada Perusahaan Manufaktur Di Indonesia)
}

\author{
oleh \\ Novitasari \\ Ayu Noviani Hanum \\ Andwiani Sinarasri \\ Email : novitamaniz359@gmail.com \\ Fakultas Ekonomi Universitas Muhammadiyah Semarang
}

\begin{abstract}
ABSTRAK
Penelitian ini bertujuan untuk menguji faktor-faktor yang berpengaruh terhadap kebijakan dividen perusahaan manufaktur (studi empiris pada perusahaan manufaktur di indonesia). Populasi dalam penelitian ini adalah perusahaan manufaktur yang terdaftar di bursa efek indonesia pada periode 2010-2012 dan periode 2009-2013. Teknik sampling yang digunakan adalah metode purposive sampling. Data sampel diperoleh dari publikasi indonesian capital market directory (icmd) 2013, indonesian capital market directory (icmd) 2014 dan www.idx.co.id, dengan menggunakan metode pooled data diperoleh jumlah sampel sebanyak 78 data pada periode 2010-2012 dan 45 data pada periode 2009-2013. Teknik analisis yang digunakan adalah regresi berganda. Tingkat signifikansi yang digunakan untuk menguji pengaruh secara simultan maupun parsial adalah sebesar 5\%.

Hasil penelitian pengamatan selama 3 tahun pada periode 2010-2012 menunjukkan bahwa variabel cash position, growth, collateralizable assets tidak berpengaruh signifikan tehadap kebijakan dividen sementara variabel return on assets dan ukuran perusahaan (firm size) berpengaruh positif dan signifikan terhadap kebijakan dividen. Sedangkan Hasil penelitian pengamatan selama 5 tahun pada periode 2009-2013 menunjukkan bahwa variabel cash position dan collateralizable assets berpengaruh positif dan signifikan terhadap kebijakan dividen sementara variabel growth, return on assets, dan ukuran perusahaan (firm size) tidak berpengaruh signifikan tehadap kebijakan dividen. Dari hasil uji koefisien determinasi diperoleh nilai adjusted r2 pada periode 2010-2012 sebesar 9,3\% sedangkan hasil uji koefisien determinasi pada periode 2009-2013 sebesar $58 \%$. Hasil uji f dari kedua pengamatan menunjukkan bahwa variabel-variabel yang digunakan dalam penelitian ini secara simultan berpengaruh signifikan terhadap variabel dependen.
\end{abstract}

kata kunci : cash position, return on assets, growth, collateralizable assets, dan firm size. 


\begin{abstract}
The purpose of this research to test the factors that influence the dividend policy of the manufacturing companies (an empirical study on manufacturing companies in Indonesia). Population in this research was manufacturing companies which listed in Indonesia stock exchange in the period of 2010-2012 and 2009-2013. The sample data was obtained from the publication of Indonesian capital market directory (ICMD) 2013, the Indonesian Capital Market Directory (ICMD) 2014 and www.idx.co.id. There were 78 samples of data in the period of 20102012 and 45 samples of data in the period of 2009-2013 by using the method of pooled data. This research used multiple regression analysis techniques and the significance level to test the effect simultaneously or partially was $5 \%$.

The results of observational research for 3 years in the period of 2010-2012 showed that the variable cash position, growth, collateralizable assets had no significant influence on dividend policy, while the variable return on assets and the size of the company (firm size) had positive and significant influence on dividend policy. Meanwhile, the results of observational research for 5 years in the period of 2009-2013 showed that the variable cash position and collateralizable assets had positive and significant influence dividend policy and the variable growth, return on assets, and the size of the company (firm size) had no significant influence on dividend policy. The test results of determination coefficient was obtained value of adjusted $r 2$ in the period of 2010 2012 amounted to $9.3 \%$ and the determination coefficient test results in the period of 2009-2013 amounted to $58 \%$. The results of $F$ test based on two observations showed that the variables that used in this research simultaneously had significant influence on the dependent variable.
\end{abstract}

Keywords: cash position, return on assets, growth, collateralizable assets, and firm size 


\section{PENDAHULUAN}

Dalam

perkembangan

perekonomian saat ini, perusahaan manufaktur dituntut untuk mampu bersaing dalam dunia industri. Perusahaan manufaktur perlu melakukan investasi untuk meningkatkan modal usaha perusahaan Untuk melakukan investasi diperlukan berbagai macam informasi tentang emiten, baik informasi kinerja perusahaan dalam bentuk laporan keuangan atau informasi lain yang relevan. Faktor-faktor yang di duga mempengaruhi kebijakan dividen (dividend payout ratio) yaitu terdiri dari cash position (CP), return on asset (ROA), pertumbuhan perusahaan (growth), collateralizable assets (COL), dan ukuran perusahaan (firm size). Faktor pertama yang diduga mempengaruhi kebijakan dividen adalah posisi kas atau likuiditas dari suatu perusahaan, merupakan faktor penting yang harus dipertimbangkan sebelum mengambil keputusan untuk menetapkan besarnya dividen yang akan dibayarkan kepada para pemegang saham. (Riyanto, 2001 dalam Marlina dan Danica, 2009).

Faktor yang kedua yaitu return on asset, return on asset (ROA) adalah rasio perbandingan net income dengan total aset. Rasio ini mengukur kemampuan perusahaan untuk menghasilkan laba yang ditanamkan dalam aset untuk kegiatan operasi perusahaan (Tita deitiana, 2009). Faktor yang ketiga yaitu kebijakan dividen dapat dipengaruhi oleh tingkat pertumbuhan perusahaan (growth). Pertumbuhan perusahaan yang tinggi akan mengurangi porsi dividen yang dibagikan kepada para pemegang saham.

Faktor yang keempat yaitu collateralizable assets atau aset-aset perusahaan yang dapat dijadikan jaminan hutang. Menurut Wahyudi dan Baidori (2008) dalam Latiefasari (2011), perusahaan dengan collateralizable assets yang tinggi memiliki agency conflict yang kecil antara pemegang saham dengan kreditor. Collateralizable assets yang tinggi akan mengurangi konflik kepentingan antara pemegang saham dengan kreditor sehingga perusahaan dapat membayar dividen dalam jumlah besar. Faktor kelima yang mempengaruhi kebijakan deviden yaitu ukuran perusahaan (firm size), firm size merupakan aspek dasar yang harus dicermati dalam melakukan keputusan investasi. Menurut Juma'h (2008) dalam Lopolusi (2013) yang menyatakan dengan semakin besar ukuran perusahaan maka pendapatan yang dihasilkan juga semakin tinggi dan menyebabkan laba yang dihasilkan untuk pembagian dividen juga tinggi. 


\section{TINJAUAN PUSTAKA}

Menurut Ang (1997), dividen yaitu nilai pendapatan bersih perusahaan setelah pajak dikurangi laba ditahan. Dividen akan dibagi kepada pemegang saham sebagai keuntungan dari laba yang diperoleh perusahaan. Sedangkan Kebijakan dividen merupakan bagian yang sudah menyatu dengan keputusan pendanaan perusahaan. Keputusannya yaitu apakah laba yang diperoleh perusahaan pada akhir tahun akan dibagikan kepada pemegang saham dalam bentuk dividen atau akan ditahan untuk menambah modal guna pembiayaan investasi di masa yang akan datang. Apabila perusahaan memilih untuk membagikan laba sebagai dividen, maka akan mengurangi laba ditahan dan selanjutnya akan mengurangi total sumber dana intern atau internal financing (Sartono, 2001 dalam Latiefasari,2011).

\section{Kerangka pemikiran dan Hipotesis}

Pengaruh Cash Position (CP) terhadap Dividend Payout Ratio (DPR).

Cash Position yaitu posisi kas sebelum mengambil suatu keputusan untuk menetapkan besarnya dividen. Karena besarnya dividen yang akan dibayarkan sangat dipengaruhi oleh besarnya posisi kas pada suatu perusahaan. Maka semakin kuatnya posisi kas atau likuiditas perusahaan menandakan akan semakin besar kemampuan perusahaan dalam membayarkan dividen kepada pemegang saham. Hasil penelitian sebelumnya Marlina dan Danica (2009) dan Taufiq (2014) menyatakan hubungan positif dan signifikan antara posisi kas dengan dividend payout ratio (DPR).

Berdasarkan Uraian diatas maka dapat diambil hipotesis sebagai berikut :

$$
\begin{aligned}
\mathrm{H} 1 & =\text { Cash Position }(\mathrm{CP}) \\
& \text { berpengaruh } \quad \text { positif } \\
& \text { terhadap Dividend Payout } \\
& \text { Ratio }(D P R) .
\end{aligned}
$$

Pengaruh Return On Assets (ROA) terhadap Dividend Payout Ratio (DPR).

Return On Assets (ROA) adalah salah satu bentuk dari rasio profitabilitas yang mengukur kemampuan perusahaan untuk menghasilkan laba dengan menggunakan total aktiva yang ada dan setelah biaya-biaya modal dikeluarkan dari analisis. Menurut Hardiatmo dan Daljono (2013), ROA memiliki pengaruh yang signifikan terhadap Kebijakan Dividen yang diukur dengan DPR (Dividend Payout Ratio). Hal ini menjelaskan bahwa semakin besar profitabilitas yang diperoleh perusahaan yang diidentifikasikan dengan nilai ROA, maka dividen yang dibagikan kepada investor juga semakin besar. 
Berdasarkan Uraian diatas maka dapat diambil hipotesis sebagai berikut :

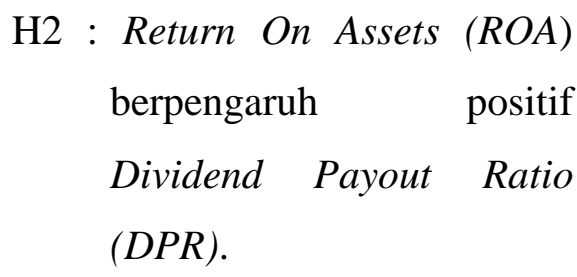

Pengaruh Pertumbuhan Perusahaan (Growth) terhadap Dividend Payout Ratio (DPR).

Growth

menunjukkan

pertumbuhan asset dimana asset merupakan aktiva yang digunakan dalam aktiva operasional perusahaan.

Perusahaan dengan tingkat pertumbuhan yang tinggi akan membutuhkan dana lebih besar dibanding perusahaan dengan tingkat pertumbuhan yang rendah. Kebutuhan dana yang besar itu disebabkan karena perusahaan membutuhkan dana lebih untuk membiayai aktivitas investasi. Maka jika pertumbuhan perusahaan tinggi pembagian dividen akan rendah (Santoso, 2012). Menurut Haryetti dan Ekayanti Pertumbuhan Perusahaan (Growth) dan Putra (2011) menyatakan bahwa berpengaruh negatif dan signifikan terhadap Dividend Payout Ratio (DPR).

Berdasarkan uraian diatas dapat diambil hipotesis sebagai berikut :

H3 : Pertumbuhan Perusahaan (Growth) berpengaruh negatif terhadap Dividend Payout Ratio (DPR).
Pengaruh Collateralizable Assets (COL) terhadap Dividend Payout Ratio (DPR).

Salah satu faktor yang mempengaruhi keputusan keuangan jangka panjang adalah tersedianya agunan. Kadang adanya pembayaran dividen yang tinggi mengakibatkan laba ditahan kemungkinan berkurang, sehingga perusahaan perlu melakukan pembiayaan melalui utang kepada kreditor. Menurut Arfan dan Maywidlan (2013) dan Latiefasari dan Chabachib (2011) menyatakan bahwa berpengaruh positif dan signifikan. Pengaruh positif tersebut bermakna bahwa semakin besar collateralizable assets akan mengakibatkan perusahaan menaikkan pembayaran dividen.

Berdasarkan uraian diatas dapat diambil hipotesis sebagai berikut :

$\mathrm{H} 4$ : Collateralizable Assets (COL) berpengaruh positif terhadap Dividend Payout Ratio (DPR).

Pengaruh Ukuran perushaan (Firm size) terhadap Dividend Payout Ratio (DPR).

Firm Size dapat dinyatakan dengan total assets. Semakin besar total assets suatu perusahaan mengindikasikan bahwa semakin besar ukuran perusahaan. Suatu perusahaan yang mapan dan besar memiliki akses yang lebih mudah di pasar modal dibandingkan dengan perusahaan yang kecil. Akses yang baik bisa 
membantu perusahaan memenuhi kebutuhan likuiditasnya. Kemudahan aksesbilitas ke pasar modal dapat diartikan adanya fleksibilitas dan kemampuan perusahaan untuk memperoleh dana dan mendapatkan laba dengan melihat pertumbuhan aset perusahaan, sehingga semakin besar ukuran perusahaan maka semakin tinggi kemungkinan perusahaan untuk membayar dividen kepada pemegang saham (Megawati, 2011). Menurut Marietta dan sampurno (2013), Puspita (2009), Santoso (2012) menyatakan bahwa firm size berpengaruh positif dan signifikan terhadap dividend payout ratio (DPR).

Berdasarkan uraian diatas dapat diambil hipotesis sebagai berikut :

H5 : Ukuran Perusahaan (firm size) berpengaruh positif terhadap Dividend Payout Ratio (DPR).

Pengaruh Cash Position (CP), Return On Assets (ROA), Pertumbuhan Perusahaan (Growth), Collateralizable Assets (COL), dan Ukuran perushaan (Firm size) secara bersama-sama (simultan) terhadap Dividend Payout Ratio (DPR).

Menurut uji $t$ atau parsial diketahui bahwa masing-masing variabel Cash Position (CP), Return On Assets (ROA), Pertumbuhan Perusahaan (Growth), Collateralizable Assets (COL), dan Ukuran perushaan (Firm size) memiliki pengaruh yang berbeda-beda namun jika diuji secara bersama-sama (simultan) variabel Cash Position (CP), Return On Assets (ROA), Pertumbuhan Perusahaan (Growth), Collateralizable Assets (COL), dan Ukuran perushaan (Firm size) memungkinkan akan berpengaruh terhadap Dividend Payout Ratio (DPR).

Berdasarkan uraian diatas dapat diambil hipotesis sebagai berikut :

H6 : Cash Position (CP), Return On Assets (ROA), Pertumbuhan Perusahaan (Growth), Collateralizable Assets (COL), dan Ukuran perushaan (Firm size) berpengaruh secara bersama-sama (simultan) terhadap Dividend Payout Ratio (DPR).

\section{METODE PENELITIAN}

\section{Populasi dan Sampel}

Populasi dalam penelitian ini adalah perusahaan manufaktur yang terdaftar di Bursa Efek Indonesia (BEI) meliputi Sektor industri dasar kimia, Sektor aneka industri, dan Sektor industri barang konsumsi berjumlah 139 perusahaan. Teknik sampling yang digunakan adalah metode purposive sampling. Sampel yang dipilih memiliki 
kriteria sebagai berikut : a. Perusahaan manufaktur yang terdaftar di BEI periode 2010 - 2012 dan periode 2009-2013. b. Perusahaan yang membagikan dividen secara kontinyu 2010 - 2012 dan periode 2009-2013. c. Perusahaan yang menerbitkan laporan keuangan secara lengkap.

Jumlah perusahaan manufaktur yang terdaftar di Bursa Efek Indonesia (BEI) adalah sebanyak 139 perusahaan. Selama periode penelitian, perusahaan yang selalu menyajikan laporan keuangan dan secara kontinyu membagikan dividen pada periode 2010-2012 dan periode 2009-2013 serta yang memenuhi kriteria penentuan sampel berjumlah 26 perusahaan pada pengamatan selama 3 tahun untuk periode 2010-2012 dan 9 perusahaan pada pengamatan selama 5 tahun untuk periode 2009-2013.

\section{Jenis dan sumber data}

Jenis dan sumber data yang digunakan dalam penelitian ini yaitu data sekunder yang diperoleh dari Indonesian Capital Market Directory (ICMD) dan website www.idx.co.id berupa laporan keuangan setiap perusahaan dari tahun 2010-2012 dan tahun 2009-2013.

\section{Teknik pengumpulan data}

Teknik pengumpulan data dalam penelitian ini dilakukan dengan dokumentasi. Dokumentasi yang dilakukan adalah dengan mengumpulkan semua data sekunder yang dipublikasikan oleh Indonesian Capital Market Directory dan www.idx.co.id tentang perusahaan yang terdaftar di Bursa Efek Indonesia selama pengamatan periode 2010 - 2012 dan periode 2009 - 2013.

\section{Teknik Analisis Data}

Penelitian ini bertujuan untuk mengetahui bagaimana pengaruh antara cash position (CP), return on asset (ROA), pertumbuhan perusahaan (growth), collateralizable assets, ukuran perusahaan (firm size) terhadap kebijakan dividen. Tekni analisis yaitu regresi berganda.

\section{Model Persamaan Regresi Berganda}

$$
\begin{aligned}
& \text { Y= } \alpha+\mathrm{b}_{1} \mathrm{x}_{1}+\mathrm{b}_{2} \mathrm{x}_{2}+\mathrm{b}_{3} \mathrm{x}_{3} \\
& +\mathrm{b}_{4} \mathrm{x}_{4}+\mathrm{b}_{5} \mathrm{x}_{5}+\mathrm{e} \\
& \text { Keterangan : } \\
& \mathrm{Y} \quad=\text { Dividend Payout Ratio } \\
& \mathrm{X} 1 \quad=\text { Cash Position }(C P) \\
& \mathrm{X} 2 \quad=\text { Return On Asset } \\
& \mathrm{X} 3 \quad=\text { Pertumbuhan Perusahaan } \\
& \mathrm{X} 4 \quad=\text { Collateralizable Assets } \\
& \mathrm{X} 5 \quad=\text { Ukuran Perusahaan } \\
& \alpha \quad=\text { Konstanta } \\
& \mathrm{b} 1-5 \quad=\text { Koefisien regresi } \\
& \mathrm{e} \quad=\text { Standar error }
\end{aligned}
$$

\section{HASIL ANALISIS DATA DAN PEMBAHASAN}

Gambaran Umum Obyek Penelitian 
Obyek penelitian yang digunakan adalah perusahaan manufaktur yang terdaftar di Bursa Efek Indonesia (BEI) periode 2010 - 2012 dan periode 20092013. Sampel dalam penelitian ini berjumlah 26 perusahaan selama pengamatan 3 tahun yaitu pada periode 2010 - 2012 dan 9 perusahaan selama pengamatan 5 tahun pada periode 20092013.

Dengan menggunakan metode penggabungan data (pooling) maka diperoleh data penelitian sebanyak $3 \times 26$ $=78$ data di periode 2010-2012 dan sebanyak 9 x $5=45$ data di periode 20092013.

\section{Deskriptif Statistik Variabel Penelitian}

Berdasarkan hasil analisis deskripsi statistik, maka pada Tabel 4.3 hasil analisis deskripsi statistik selama pengamatan 3 tahun pada periode 2010 2012 dan Tabel 4.4 hasil analisis deskripsi statistik selama pengamatan 5 tahun pada periode 2009 - 2013.

Tabel 4.3

Hasil Analisis Deskriptif Data periode 2010 - 2012

\begin{tabular}{|c|c|c|c|c|c|}
\hline & N & Minimum & Maximum & Mean & $\begin{array}{c}\text { Std. } \\
\text { Deviation }\end{array}$ \\
\hline DPR & 78 & 0,07 & 928,57 & 48,7226 & 106,59418 \\
\hline CP & 78 & 0,06 & 589,86 & 119,7027 & 99,99009 \\
\hline ROA & 78 & 0,81 & 41,56 & 14,8132 & 10,19021 \\
\hline GROWTH & 78 & $-5,63$ & 59,47 & 16,8890 & 12,66552 \\
\hline COL & 78 & 10,53 & 78,80 & 36,2610 & 16,22612 \\
\hline FS & 78 & 12,91 & 19,02 & 15,4013 & 1,51304 \\
\hline $\begin{array}{c}\text { Valid N } \\
\text { (listwise) }\end{array}$ & 78 & & & & \\
\hline
\end{tabular}

Sumber: Data sekunder yang diolah

Tabel 4.4

Hasil Analisis Deskriptif Data periode 2009 - 2013

\begin{tabular}{|c|r|r|r|r|r|}
\hline & \multicolumn{1}{|c|}{ N } & Minimum & Maximum & \multicolumn{1}{c|}{ Mean } & \multicolumn{1}{c|}{$\begin{array}{c}\text { Std. } \\
\text { Deviation }\end{array}$} \\
\hline DPR & 45 & 0,07 & 928,57 & 58,0642 & 138,29659 \\
\hline CP & 45 & 12,20 & 589,86 & 134,5682 & 122,31054 \\
\hline ROA & 45 & 1,65 & 66,91 & 15,0082 & 12,33895 \\
\hline GROWTH & 45 & $-7,87$ & 75,72 & 15,6787 & 15,08830 \\
\hline COL & 45 & 13,95 & 63,19 & 36,3947 & 15,19320 \\
\hline FS & 45 & 13,56 & 17,86 & 15,1396 & 1,36651 \\
\hline $\begin{array}{c}\text { Valid N } \\
\text { (listwise) }\end{array}$ & 45 & & & & \\
\hline
\end{tabular}

Sumber: Data sekunder yang diolah

Dari Hasil kedua Tabel diatas, dan standar deviasi lebih kecil dari nilai dapat dijelaskan bahwa jika standar mean-nya dikatakan memiliki sebaran deviasi lebih besar dari nilai mean-nya yang kecil.

dikatakan memiliki sebaran yang besar

Pengujian Asumsi Klasik 
Uji Normalitas

A. Selama pengamatan 3 tahun untuk periode 2010-2012
Hasil pengujian normalitas dengan dengan one-sample kolmogorov-smirnov test tampak dalam Tabel 4.5 sebagai berikut :

Tabel 4.5

Normalitas Data

\begin{tabular}{|c|c|c|}
\hline $\mathrm{N}$ & Kolmogorov-Smirnov Z & Asymp. Sig. \\
\hline 78 & 1,485 & 0,024 \\
\hline
\end{tabular}

Sumber : Data sekunder diolah

Berdasarkan uji one-sample menandakan bahwa data tidak kolmogorov-smirnov test terlihat nilai terdistribusi dengan normal. Untuk itu signifikansi 0,024 dibawah 0,05 diperlukan uji outlier sebagai berikut:

Tabel 4.6

Data Outlier

\begin{tabular}{|l|l|l|l|l|l|}
\hline ZDPR & ZCP & ZROA & ZGROWTH & ZCOL & ZFS \\
\hline 8,25418 & 3,00732 & 2,62475 & 3,336196 & - & - \\
\hline 6,53760 & & & 3,11642 & & \\
\hline
\end{tabular}

Sumber: Data yang diolah

Berdasarkan uji outlier terdapat 6 terlihat nilai signifikansi 0,493 jauh diatas data yang outlier. Data outlier adalah data 0,05 yang menandakan bahwa data sudah yang memiliki nilai berkisar $>2,5$. terdistribusi dengan normal dengan Setelah uji outlier dilakukan kembali uji melihat tabel dibawah ini:

one-sample kolmogorov-smirnov test

Tabel 4.7

Normalitas Data

\begin{tabular}{|c|c|c|}
\hline $\mathrm{N}$ & Kolmogorov-Smirnov Z & Asymp. Sig. \\
\hline 72 & 0,832 &, 493 \\
\hline
\end{tabular}

Sumber : Data sekunder yang diolah

Hasil pengujian data normalitas

juga didukung dengan grafik 4.1 normal

plot dibawah ini : 


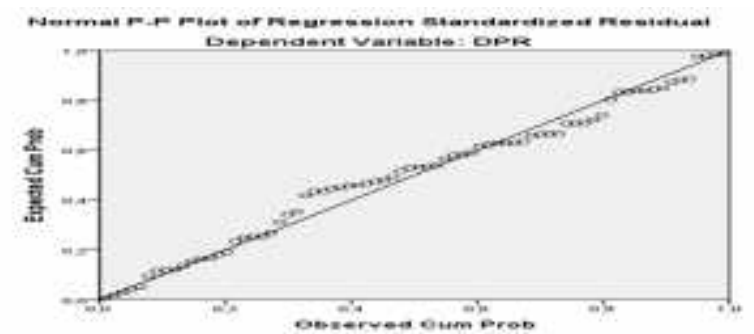

B. Selama pengamatan 5 tahun untuk periode 2009-2013

smirnov test tampak dalam Tabel 4.8

Hasil pengujian normalitas

dengan dengan one-sample kolmogorov-

Tabel 4.8

Normalitas data

\begin{tabular}{|c|c|c|}
\hline $\mathrm{N}$ & Kolmogorov-Smirnov Z & Asymp. Sig. \\
\hline 45 & 1,292 & 0,071 \\
\hline
\end{tabular}

Sumber : Data sekunder yang diolah

Berdasarkan uji one-sample

dengan normal. Akan tetapi 3 data harus kolmogorov-smirnov test terlihat nilai dihilangkan agar semua pengujian asumsi signifikansi 0,071 diatas 0,05 yang klasik dapat terpenuhi. Pada tabel 4.9 menandakan bahwa data terdistribusi akan disajikan data outlier.

Tabel 4.9

Data outlier

\begin{tabular}{|l|l|l|l|l|l|}
\hline ZDPR & ZCP & ZROA & ZGROWTH & ZCOL & ZFS \\
\hline 5,71672 & 3,69888 & - & 2,58554 & - & - \\
\hline
\end{tabular}

Setelah uji outlier dilakukan 0,431 jauh diatas 0,05 yang menandakan kembali uji one-sample kolmogorovbahwa data sudah terdistribusi dengan smirnov test terlihat nilai signifikansi normal dengan melihat tabel dibawah ini :

Tabel 4.10

Normalitas Data

\begin{tabular}{|c|c|c|}
\hline $\mathrm{N}$ & Kolmogorov-Smirnov Z & Asymp. Sig. \\
\hline 42 & 0,873 & 0,431 \\
\hline
\end{tabular}

Sumber : Data sekunder yang diolah

Uji Multikolinearitas

A. Selama pengamatan 3 tahun untuk periode 2010-2012
Untuk mengetahui ada tidaknya multikolinearitas di dalam model regresi dapat dilihat dari nilai Tolerance dan Variance Inflation Factor (VIF).

Tabel 4.11

Coefficients $^{\mathrm{a}}$

\section{Hasil Uji Multikolinearitas}

\begin{tabular}{|l|l|}
\hline Model Collinearity Statistics \\
\hline
\end{tabular}




\begin{tabular}{|l|r|r|}
\hline & Tolerance & \multicolumn{1}{l|}{ VIF } \\
\hline (Constant) & & \\
CP &, 744 & 1,344 \\
ROA &, 806 & 1,240 \\
GROWTH &, 864 & 1,157 \\
COL &, 894 & 1,118 \\
FS &, 883 & 1,132 \\
\hline
\end{tabular}

a. Dependent Variable: DPR

Sumber : Data sekunder yang diolah

Dari Tabel 4.11 dapat diketahui bahwa semua variabel independen memiliki nilai Tolerance di atas 0.1 dan nilai VIF jauh di bawah angka 10 . Hal ini B. Selama pengamatan 5 tahun untuk periode 2009 - 2013

Hasil pengujian multikolinearitas menunjukkan dalam model ini tidak terjadi multikolinearitas.

Tabel 4.12

Coefficients $^{\mathrm{a}}$

Hasil Uji Multikolinearitas

\begin{tabular}{|c|c|c|c|}
\hline & \multicolumn{2}{|c|}{ Collinearity Statistics } \\
\hline \multicolumn{2}{|c|}{ 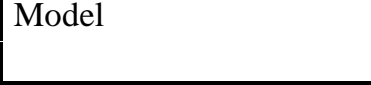 } & \multirow[t]{2}{*}{ Tolerance } & VIF \\
\hline \multirow{6}{*}{1} & (Constant) & & \multirow{6}{*}{$\begin{array}{l}1,634 \\
1,512 \\
1,292 \\
1,191 \\
1,555\end{array}$} \\
\hline & $\mathrm{CP}$ & \multirow{5}{*}{$\begin{array}{l}, 612 \\
, 661 \\
, 774 \\
, 840 \\
643\end{array}$} & \\
\hline & ROA & & \\
\hline & GROWTH & & \\
\hline & $\mathrm{COL}$ & & \\
\hline & FS & & \\
\hline
\end{tabular}

a. Dependent Variable: DPR

Sumber : Data sekunder yang diolah

Tabel 4.12 dapat diketahui bahwa semua variabel independen memiliki nilai Tolerance di atas 0.1 dan nilai VIF jauh di bawah angka 10. Hal ini menunjukkan dalam model ini tidak terjadi multikolinearitas.

Data yang digunakan untuk uji heteroskedastisitas ini adalah data dari variabel independen setelah outlier dihilangkan. Hasil uji heteroskedastisitas dengan menggunakan grafik scatterplot di tunjukan pada Grafik 4.2 di bawah ini:

\section{Uji Heterokedastisitas}

A. Selama pengamatan 3 tahun untuk

Grafik 4.2

Grafik Scatterplot periode 2010-2012 


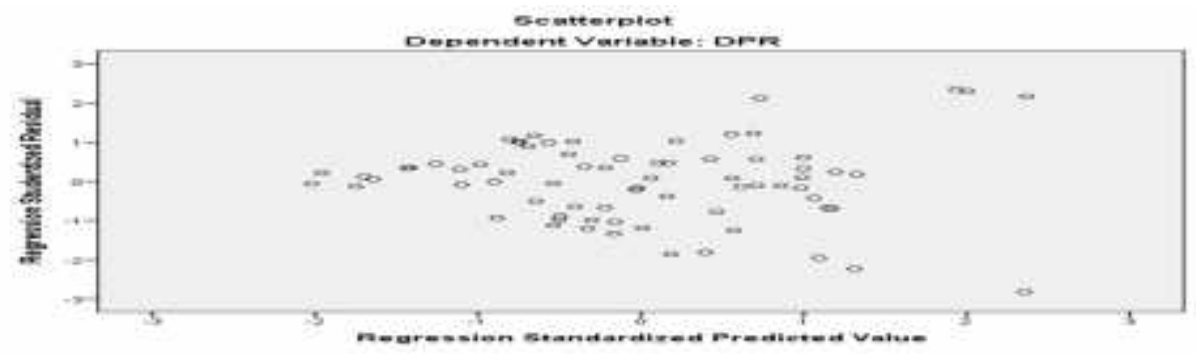

Sumber : Data sekunder yang diolah

Dari grafik scatterplot terlihat bahwa titik-titik menyebar secara acak serta tersebar baik di atas maupun di bawah angka 0 pada sumbu Y. Dengan demikian dapat disimpulkan bahwa model regresi ini tidak terjadi heteroskedastisitas. Hasil ini juga didukung dengan Metode korelasi Spearman's rho yaitu mengkorelasikan variabel independen dengan nilai unstandardized residual. Pengujian menggunakan tingkat signifikansi 0,05 dengan uji 2 sisi. Lihat pada tabel 4.13 sebagai berikut :

Tabel

korelasi Spearman's rho Correlations

\begin{tabular}{|c|c|c|c|c|c|c|c|c|}
\hline & & & $\mathrm{CP}$ & $\mathrm{ROA}$ & GROWTH & COL & FS & $\begin{array}{c}\text { Unstandard } \\
\text { ized } \\
\text { Residual }\end{array}$ \\
\hline \multirow{19}{*}{ Spearman's rho } & \multirow{4}{*}{$\mathrm{CP}$} & Correlation & 1,000 & $-.413^{* *}$ & -133 & & -.074 & -.031 \\
\hline & & Coefficient & & & & ,294 & & \\
\hline & & Sig. (2-tailed) & & ,000 & ,256 & ,009 &, 524 & ,797 \\
\hline & & $\mathrm{N}$ & 77 & 76 & 75 & 77 & 77 & 72 \\
\hline & \multirow{3}{*}{ ROA } & $\begin{array}{l}\text { Correlation } \\
\text { Coefficient }\end{array}$ &,$- 413^{* *}$ & 1,000 &, $298^{* *}$ &,- 003 &, 160 &, 042 \\
\hline & & Sig. (2-tailed) &, 000 & . & ,010 & ,981 & , 163 & ,728 \\
\hline & & $\mathrm{N}$ & 76 & 77 & 75 & 77 & 77 & 72 \\
\hline & \multirow{3}{*}{ GROWTH } & $\begin{array}{l}\text { Correlation } \\
\text { Coefficient }\end{array}$ &,- 133 &, $298^{* *}$ & 1,000 &,- 085 &, $389^{\text {*** }}$ &,- 051 \\
\hline & & Sig. (2-tailed) &, 256 & 010 & & ,464 & ,001 & ,672 \\
\hline & & $\mathrm{N}$ & 75 & 75 & 76 & 76 & 76 & 72 \\
\hline & \multirow{3}{*}{ COL } & $\begin{array}{l}\text { Correlation } \\
\text { Coefficient }\end{array}$ &,$- 294^{* *}$ &,- 003 &,- 085 & 1,000 &,- 034 &,- 027 \\
\hline & & Sig. (2-tailed) & ,009 & ,981 & ,464 & & ,765 &, 825 \\
\hline & & $\mathrm{N}$ & 77 & 77 & 76 & 78 & 78 & 72 \\
\hline & \multirow{3}{*}{ FS } & $\begin{array}{l}\text { Correlation } \\
\text { Coefficient }\end{array}$ &,- 074 &, 160 &, $389^{* *}$ &,- 034 & 1,000 &,- 056 \\
\hline & & Sig. (2-tailed) &, 524 & ,163 &, 001 &, 765 & . & ,641 \\
\hline & & $\mathrm{N}$ & 77 & 77 & 76 & 78 & 78 & 72 \\
\hline & \multirow{3}{*}{$\begin{array}{l}\text { Unstandardized } \\
\text { Residual }\end{array}$} & $\begin{array}{l}\text { Correlation } \\
\text { Coefficient }\end{array}$ &,- 031 & ,042 &,- 051 &,- 027 &,- 056 & 1,000 \\
\hline & & Sig. (2-tailed) &, 797 &, 728 & ,672 &, 825 & ,641 & . \\
\hline & & $\mathrm{N}$ & 72 & 72 & 72 & 72 & 72 & 72 \\
\hline
\end{tabular}


**. Correlation is significant at the 0.01 level (2-tailed).

Sumber: Data sekunder yang diolah

Dari output di atas dapat diketahui

B. Selama pengamatan 5 tahun untuk bahwa nilai korelasi kelima variabel independen dengan Unstandardized periode $2009-2013$

Hasil uji heteroskedastisitas Residual memiliki nilai signifikansi lebih dari 0,05. Karena signifikansi lebih dari dengan menggunakan grafik scatterplot di tunjukan pada Grafik 4.3 di bawah ini: 0,05 maka dapat disimpulkan bahwa tidak terjadi masalah heteroskedastisitas pada model regresi.

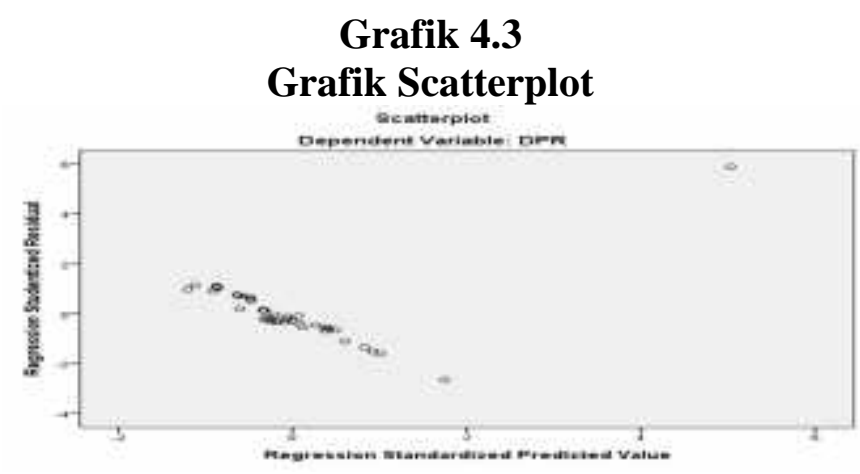

Sumber : Data sekunder yang diolah

Hasil ini juga didukung dengan Metode Uji park. Lihat tabel 4.14 sebagai berikut :

Tabel 4.14

Uji park

Coefficients $^{\mathrm{a}}$

\begin{tabular}{|c|c|c|c|c|c|c|}
\hline \multirow{2}{*}{\multicolumn{2}{|c|}{ Model }} & \multicolumn{2}{|c|}{ Unstandardized Coefficients } & \multirow{2}{*}{$\begin{array}{c}\begin{array}{c}\text { Standardized } \\
\text { Coefficients }\end{array} \\
\text { Beta }\end{array}$} & \multirow[t]{2}{*}{$\mathrm{t}$} & \multirow[t]{2}{*}{ Sig. } \\
\hline & & $\mathrm{B}$ & Std. Error & & & \\
\hline \multirow{6}{*}{1} & (Constant) & 8,265 & 3,918 & & 2,110 &, 042 \\
\hline & $\mathrm{CP}$ & ,006 & ,003 &, 320 & 1,754 & ,088 \\
\hline & ROA &,- 056 & 036 &,- 274 & $-1,565$ & , 126 \\
\hline & GROWTH &, 004 & 022 & ,026 &, 162 &, 872 \\
\hline & COL &, 003 & 020 & ,024 &, 154 &, 879 \\
\hline & FS &,- 068 &, 251 &,- 048 &,- 270 & ,789 \\
\hline
\end{tabular}


Sumber : Data sekunder yang diolah

Dari output di atas dapat diketahui bahwa nilai korelasi kelima variabel independen dengan nilai signifikansi lebih dari 0,05. Karena signifikansi lebih dari 0,05 maka dapat disimpulkan bahwa tidak terjadi masalah heteroskedastisitas pada model regresi.

\section{Uji Autokorelasi}

A. Selama pengamatan 3 tahun untuk periode 2010-2012

Dengan menggunakan uji durbin-watson :

Tabel 4.15

Uji durbin-watson

\section{Model Summary}

\begin{tabular}{|c|c|c|c|c|c|}
\hline Model & $\mathrm{R}$ & $\mathrm{R}$ Square & $\begin{array}{c}\text { Adjusted R } \\
\text { Square }\end{array}$ & $\begin{array}{c}\text { Std. Error of the } \\
\text { Estimate }\end{array}$ & Durbin-Watson \\
\hline 1 &, $396^{\mathrm{a}}$ &, 157 &, 093 & 21,92499 & 1,077 \\
\hline
\end{tabular}

a. Predictors: (Constant), FS, COL, ROA, GROWTH, CP

b. Dependent Variable: DPR

Sumber : Data sekunder yang diolah

Berdasar hasil analisis regresi mengatasi masalah autokorelasi dengan pada Tabel 4.15 dapat disimpulkan bahwa terdapat autokorelasi. Oleh karena itu menggunakan uji Runs Test. Lihat pada perlu dilakukan pengobatan untuk Tabel 4.16 sebagai berikut :

Tabel 4.16

Runs Test

\begin{tabular}{|c|c|c|}
\hline $\mathrm{N}$ & Runs Test & Asymp. Sig. \\
\hline 42 & 1,71232 & 0,058 \\
\hline
\end{tabular}

Sumber : Data sekunder diolah

\section{Berdasarkan output SPSS}

menunjukkan bahwa residual random atau tidak terjadi autokorelasi antar nilai residual.
B. Selama pengamatan 5 tahun untuk periode 2009-2013

Untuk mengetahui ada tidaknya autokorelasi kita harus melihat nilai uji DW dengan ketentuan sbb :

Tabel 4.17

Uji Durbin-Watson

Model Summary ${ }^{b}$

\begin{tabular}{|l|r|r|r|r|r|}
\hline Model & $\mathrm{R}$ & $\mathrm{R}$ Square & $\begin{array}{c}\text { Adjusted R } \\
\text { Square }\end{array}$ & $\begin{array}{c}\text { Std. Error of the } \\
\text { Estimate }\end{array}$ & Durbin-Watson \\
\hline 1 &, $795^{\mathrm{a}}$ &, 631 &, 580 & 90,28060 & 1,728 \\
\hline
\end{tabular}

a. Predictors: (Constant), FS, ROA, COL, GROWTH, CP 
b. Dependent Variable: DPR

Sumber : Data sekunder diolah

Berdasar hasil analisis regresi

pada Tabel 4.17 dapat disimpulkan bahwa tidak ada autokorelasi (lihat tabel keputusan) atau dapat disimpulkan tidak terdapat autokorelasi.

Pengujian Hipotesis, Analisis Koefisien

Determinasi (R2), Uji Statisik F, dan

Uji Statistik t

A. Selama pengamatan 3 tahun untuk periode 2010-2012

Hasil hipotesis, analisis koefisien determinasi (r2), uji statisik f, dan uji statistik t dilihat pada tabel 4.20 sebagai berikut :

Tabel 4.20

Hasil Pengujian statistik

\begin{tabular}{|l|c|c|c|}
\hline \multicolumn{1}{|c|}{ Variabel } & $\mathrm{t}$ & Sig t & Hipotesis \\
\hline Cash position (X1) & 0,848 & $40 \%$ & Ditolak \\
\hline Return on assets (X2) & 2,720 & $0,8 \%$ & Diterima \\
\hline Growth (X3) & $-1,905$ & $6,1 \%$ & Ditolak \\
\hline Collateralizable assets (X4) & 0,045 & $96,4 \%$ & Ditolak \\
\hline Firm size (X5) & 2,194 & $3,2 \%$ & Diterima \\
\hline R Square & $=15,7 \%$ & & \\
\hline Adjusted R Square & $=9,3 \%$ & & \\
\hline F & $=2,457$ & & \\
\hline Sig F & $=4,2 \%$ & & \\
\hline Variabel dependen = DPR (Y) & $=2,35$ & & \\
\hline F Tabel & $=1,9939$ & & \\
\hline T Tabel & & & \\
\hline
\end{tabular}

Sumber : Data Sekunder yang Diolah Berdasar output SPSS tampak

bahwa dari hasil perhitungan diperoleh nilai koefisien determinasi (R2) pada perusahaan yang terdaftar di Bursa Efek Indonesia periode 2010-2012 sebesar 15,7\%. sedangkan Adjusted $R$ Square sebesar $9,3 \%$.

Nilai pembanding yang digunakan dalam uji $f$ adalah nilai $f$ tabel. Nilai $f$ tabel $(2,35)$ diperoleh dengan tingkat signifikansi 0,05 dan df $=72-1-5=66$. Dilihat dari hasil output SPSS analisis regresi dapat diperoleh $f$ hitung sebesar 2,457 . Karena f hitung lebih besar dari $\mathrm{f}$ tabel atau tingkat signifikansinya 4,2\% lebih kecil dari 5\% maka H0 ditolak. Hal ini berarti bahwa secara bersama-sama variabel independen memiliki pengaruh yang signifikan terhadap variabel dependen.

Nilai pembanding yang digunakan dalam uji $\mathrm{t}$ adalah nilai $\mathrm{t}$ tabel. Nilai $\mathrm{t}$ tabel $(1,9939)$ diperoleh dengan tingkat signifikansi 0,05 dan df $=72-1=71$. Berdasarkan tabel di atas dapat diinterpretasikan sebagai berikut:

a. Variabel cash position (CP) berdasarkan hasil pengujian 
tersebut, diperoleh $\mathrm{t}$ hitung sebesar 0,848. Karena t hitung kurang dari $\mathrm{t}$ tabel maka $\mathrm{H} 0$ diterima. Hal ini berarti variabel cash position $(\mathrm{CP})$ tidak memiliki pengaruh secara parsial atau signifikan terhadap variabel dividend payout ratio (DPR). Penelitian ini sejalan dengan penelitian hasil Karjono dan Matondang (2010) dan Putra (2011) yang menyatan positif dan tidak signifikan. Hal ini disebabkan karena Perusahaan menahan cash position untuk menjalankan kegiatan operasional perusahaan dan untuk membiayai investasi dalam bentuk aktiva riil. Tetapi hasil ini tidak sesuai dengan hasil penelitian Marlina dan Danica (2009) yang menyatakan bahwa cash position (CP) berpengaruh positif dan signifikan.

b. Variabel return on assets (ROA) berdasarkan hasil pengujian tersebut, diperoleh thitung sebesar 2,720. Karena t hitung lebih besar dari $\mathrm{t}$ tabel maka H0 ditolak. Hal ini berarti variabel return on assets (ROA) memiliki pengaruh secara parsial atau signifikan terhadap variabel dividend payout ratio (DPR). Hasil penelitian ini serupa dengan Marlina dan Danica (2009) dan Hardiatmo dan Daljono yang menyatakan ROA berpengaruh positif dan signifikan. Hal ini menandakan bahwa pada tingkat profitabilitas yang tinggi dapat menentukan besarnya deviden yang akan diterima oleh investor

c. Variabel pertumbuhan perusahaan (growth) berdasarkan hasil pengujian tersebut, diperoleh $\mathrm{t}$ hitung sebesar $-1,905$. Karena $\mathrm{t}$ hitung lebih kecil dari $t$ tabel maka H0 diterima. Hal ini berarti variabel pertumbuhan perusahaan (growth) tidak memiliki pengaruh secara parsial atau signifikan terhadap variabel dividend payout ratio (DPR). Penelitian ini konsisten dengan hasil penelitian Lopolusi (2013) dan Marietta dan Sampurno (2013) menyatakan bahwa pertumbuhan perusahaan (growth) berpengaruh negatif dan tidak signifikan. Hal disebabkan karena perusahaan besar cenderung memiliki alternatif pendanaan yang lebih banyak, sehingga perusahaan menjadi kurang bergantung pada pendanaan internal. Sementara itu, hasil penelitian ini tidak mendukung hasil penelitian Putra 
(2011) yang menyatakan negatif dan signifikan.

d. Variabel collateralizable assets (COL) Berdasarkan hasil pengujian tersebut, diperoleh $\mathrm{t}$ hitung sebesar 0,045. Karena t hitung lebih kecil dari t tabel atau maka H0 diterima. Hal ini berarti variabel collateralizable assets (COL) berpengaruh positif tetapi tidak memiliki pengaruh secara parsial atau signifikan terhadap variabel dividend payout ratio (DPR). Penelitian ini konsisten dengan penelitian Santoso (2012) menyatakan bahwa collateralizable assets (COL) berpengaruh positif dan tidak signifikan. Alasan tidak ditemukannya pengaruh yang signifikan dari variabel collateralizable assets diduga disebabkan karena rendahnya tingkat hutang obligasi di Indonesia. Akibatnya, collateralizable assets sebagai faktor yang dapat menjembatani kepentingan kedua pihak tersebut tidak memiliki pengaruh yang signifikan dalam pengambilan keputusan kebijakan dividen pada perusahaan manufaktur yang terdaftar di Bursa Efek Indonesia (BEI) (Santoso, 2012). Tetapi
Hasil Penelitian ini tidak sesuai dengan hasil penelitian Arfan dan Maywidlan (2013) yang menyatakan bahwa collateralizable assets (COL) berpengaruh positif dan signifikan terhadap dividend payout ratio (DPR).

e. Variabel ukuran perusahaan (firm size) Berdasarkan hasil pengujian tersebut, diperoleh $\mathrm{t}$ hitung sebesar 2,194. Karena t hitung lebih besar dari t tabel maka H0 ditolak. Hal ini berarti variabel ukuran perusahaan (firm size) memiliki pengaruh secara parsial atau signifikan terhadap variabel dividend payout ratio (DPR). Hasil penelitian ini sejalan dengan hasil penelitian Marietta dan Sampurno (2013), dan Sutrisno (2009) yang menyatakan bahwa ukuran perusahaan (firm size) berpengaruh positif dan signifikan, Hal ini disebabkan karena semakin besar ukuran perusahaan suatu perusahaan yang mapan dan besar memiliki akses yang lebih mudah di pasar modal dibandingkan dengan perusahaan yang kecil.

B. Selama pengamatan 5 tahun untuk periode 2009-2013

Hasil hipotesis, analisis koefisien determinasi (r2), uji statisik $f$, dan uji 
statistik $\mathrm{t}$ dilihat pada tabel 4.21 sebagai berikut:

Tabel 4.21

Hasil Pengujian statistik

\begin{tabular}{|c|c|c|c|}
\hline Variabel & $\mathrm{t}$ & Sig t & Hipotesis \\
\hline Cash position (X1) & 7,127 & $0,0 \%$ & Diterima \\
\hline Return on assets (X2) & 1,386 & $17,4 \%$ & Ditolak \\
\hline Growth (X3) & 0,129 & $89,8 \%$ & Ditolak \\
\hline Collateralizable assets (X4) & 2,343 & $2,5 \%$ & Diterima \\
\hline Firm size (X5) & 1,136 & $26,4 \%$ & Ditolak \\
\hline R Square & \multirow{4}{*}{$\begin{array}{l}=63,1 \% \\
=58,0 \% \\
=12,329 \\
=0,0 \%\end{array}$} & & \\
\hline Adjusted R Square & & & \\
\hline $\mathrm{F}$ & & & \\
\hline Sig F & & & \\
\hline \multicolumn{4}{|l|}{ Variabel dependen $=$ DPR $(Y)$} \\
\hline F Tabel & \multirow{2}{*}{$\begin{array}{l}=2,48 \\
=2,0195\end{array}$} & & \\
\hline T Tabel & & & \\
\hline
\end{tabular}

Sumber : Data sekunder yang diolah

Berdasar output SPSS tampak

bahwa dari hasil perhitungan diperoleh nilai koefisien determinasi (R2) pada perusahaan yang terdaftar di Bursa EfekIndonesia periode 2009-2013 sebesar 63,1\%. sedangkan Adjusted $R$ Square sebesar $58 \%$.

Nilai pembanding yang digunakan dalam uji $\mathrm{f}$ adalah nilai $\mathrm{f}$ tabel. Nilai $\mathrm{f}$ tabel $(2,48)$ diperoleh dengan tingkat signifikansi 0,05 dan df $=42-1-5=36$. Dilihat dari hasil output SPSS analisis regresi dapat diperoleh $f$ hitung sebesar 12,329. Karena f hitung lebih besar dari $\mathrm{f}$ tabel atau tingkat signifikansinya $0 \%$ lebih kecil dari 5\% maka H0 ditolak. Hal ini berarti bahwa secara bersama-sama variabel independen memiliki pengaruh yang signifikan terhadap variabel dependen.

Nilai pembanding yang digunakan dalam uji $\mathrm{t}$ adalah nilai $\mathrm{t}$ tabel. Nilai $\mathrm{t}$ tabel $(2,0195)$ diperoleh dengan tingkat signifikansi 0,05 dan df $=42-1=41$.

Berdasarkan tabel di atas dapat diinterpretasikan sebagai berikut:

a. Variabel cash position (CP) berdasarkan hasil pengujian tersebut, diperoleh $\mathrm{t}$ hitung sebesar 7,127. Karena $t$ hitung lebih dari t tabel maka H0 ditolak. Hal ini berarti variabel cash position (CP) memiliki pengaruh secara parsial atau signifikan terhadap variabel dividend payout ratio (DPR). Hasil ini sesuai dengan hasil penelitian Marlina dan Danica (2009) yang menyatakan bahwa cash position (CP) berpengaruh positif dan signifikan.

b. Variabel return on assets (ROA) berdasarkan hasil pengujian tersebut, diperoleh $\mathrm{t}$ hitung 
sebesar 1,386. Karena t hitung kurang dari $\mathrm{t}$ tabel maka $\mathrm{H} 0$ diterima. Hal ini berarti variabel return on assets (ROA) tidak memiliki pengaruh secara parsial atau signifikan terhadap variabel dividend payout ratio (DPR). Hasil penelitian ini sesuai dengan penelitian Deitiana (2009) dan Sumiaji (2011) yang menyatakan return on assets (ROA) berpengaruh positif dan tidak signifikan terhadap dividend payout ratio (DPR). Walaupun tidak signifikan, arah pengaruh positif menunjukkan kemungkinan indikasi bahwa perusahaan memiliki tingkat profitabilitas tinggi akan membagikan dividen dalam jumlah yang tinggi pula.

c. Variabel pertumbuhan perusahaan (growth) berdasarkan hasil pengujian tersebut, diperoleh thitung sebesar 0,129. Karena t hitung lebih kecil dari $\mathrm{t}$ tabel maka H0 diterima. Hal ini berarti variabel pertumbuhan perusahaan (growth) tidak memiliki pengaruh secara parsial atau signifikan terhadap variabel dividend payout ratio (DPR).

d. Variabel collateralizable assets $(\mathrm{COL})$ berdasarkan hasil pengujian tersebut, diperoleh $\mathrm{t}$ hitung sebesar 2,343. Karena $\mathrm{t}$ hitung lebih dari t tabel maka H0 ditolak. Hal ini berarti variabel collateralizable asssets memiliki pengaruh secara parsial atau signifikan terhadap variabel dividend payout ratio (DPR). Hasil ini sesuai dengan teori keagenan yang mengatakan Perusahaan dengan collateralizable assets yang tinggi memiliki masalah agensi yang lebih kecil antara pemegang saham dan pemegang obligasi. Alasan yang mendasari adalah perusahaan dengan collateralizable assets yang tinggi dapat menggunakan aset tersebut sebagai jaminan untuk hutang. Hal ini sesuai dengan hasil penelitian Wahyudi dan Baidori (2008) yang menyatakan bahwa collateralizable assets berpengaruh positif dan signifikan terhadap kebijakan dividen.

e. Variabel ukuran perusahaan (firm size) Berdasarkan hasil pengujian tersebut, diperoleh $\mathrm{t}$ hitung sebesar 1,136. Karena $\mathrm{t}$ hitung lebih kecil dari t tabel maka H0 diterima. Hasil penelitian ini sesuai dengan penelitian Karjono dan Matondang (2010) yang 
menyatakan ukuran perusahaan (firm size) berpengaruh positif dan tidak signifikan terhadap dividend payout ratio (DPR). Hal ini berarti variabel ukuran perusahaan (firm size) tidak memiliki pengaruh secara parsial atau signifikan terhadap variabel dividend payout ratio (DPR). Hal ini disebabkan oleh keadaan iklim ekonomi yang belum begitu stabil, sehingga perusahaan dalam menjalankan usahanya tidak efektif dalam mengelola dana dan membuat laba yang dihasilkan tidak maksimal.

\section{KESIMPULAN}

1. Hasil penelitian dari kedua pengamatan, menunjukkan bahwa pengamatan selama 5 tahun periode 2009 - 2013 diperoleh $58 \%$ lebih baik daripada pengamatan selama 3 tahun periode 2010 - 2012 diperoleh 9,3\%.

2. Hasil cash position (CP) berpengaruh positif dan tidak signifikan terhadap dividend payout ratio (DPR) pada perusahaan manufaktur yang terdaftar di Bursa Efek Indonesia periode 2010-2012. Dan cash position (CP) berpengaruh positif dan signifikan terhadap dividend payout ratio (DPR) pada perusahaan manufaktur yang terdaftar di Bursa Efek Indonesia periode 2009-2013.

3. Hasil return on assets (ROA) berpengaruh positif dan signifikan terhadap dividend payout ratio (DPR) pada perusahaan manufaktur yang terdaftar di Bursa Efek Indonesia periode 2010-2012. Dan return on assets (ROA) berpengaruh positif dan tidak signifikan terhadap dividend payout ratio (DPR) pada perusahaan manufaktur yang terdaftar di Bursa Efek Indonesia periode 2009-2013. 4. Hasil pertumbuhan perusahaan (growth) berpengaruh negatif dan tidak signifikan terhadap dividend payout ratio (DPR) pada perusahaan manufaktur yang terdaftar di Bursa Efek Indonesia periode 2010-2012. Dan pertumbuhan perusahaan (growth) berpengaruh poitif dan tidak signifikan terhadap dividend payout ratio (DPR) pada perusahaan manufaktur yang terdaftar di Bursa Efek Indonesia periode 2009-2013. 
5. Hasil collateralizable assets (COL) berpengaruh positif dan tidak signifikan terhadap dividend payout ratio (DPR) pada perusahaan manufaktur yang terdaftar di Bursa Efek Indonesia periode 2010-2012. Dan collateralizable assets (COL) berpengaruh positif dan signifikan terhadap dividend payout ratio (DPR) pada perusahaan manufaktur yang terdaftar di Bursa Efek Indonesia periode 2009-2013.

6. Hasil ukuran perusahaan (firm size) berpengaruh positif dan signifikan terhadap dividend payout ratio (DPR) pada perusahaan manufaktur yang terdaftar di Bursa Efek Indonesia periode 2010-2012. ukuran perusahaan (firm size) berpengaruh positif dan tidak signifikan terhadap dividend payout ratio (DPR) pada perusahaan manufaktur yang terdaftar di Bursa Efek Indonesia periode

\section{SARAN}

1. Dalam penelitian mendatang perlu menambahkan variabel-variabel lain yang mempengaruhi dividend payout ratio (DPR) variabel yang dapat ditambahkan dalam penelitian ini adalah tingkat inflasi, suku bunga, indeks harga konsumen, tingkat risiko pasar, growth of sales, net profit income, earning per share dan lain-lain.

2. Menambahkan jumlah sampel dalam waktu pengamatan yang lebih lama sehingga nantinya diharapkan hasil yang diperoleh akan lebih dapat digeneralisasikan.

3. Tidak hanya perusahaan manufaktur saja tetapi seluruh perusahaan yang terdaftar di Bursa Efek Indonesia (BEI).

\section{DAFTAR PUSTAKA}

Aang, Robert, 1997, Buku Pintar Pasar Modal Indonesia (The Intelligent Guide To Indonesian Capital Market ), Media Soft Indonesia, Jakarta (Diakses 28 November 2014)

Al-Malkawi, H.N. 2007. "Determinants of Corporate Dividend Policy in Jordan: an Application of The Tobit Model". Journal of Applied Accounting Research, Vol. 23, pp. 44-70.

Arimawati, Rizki, 2011, “Analisis Pengaruh Cash Position, Return On Equity, Debt To Equity Ratio, Company's Growth Dan Collateralizable Assets Terhadap Dividend Payout Ratio Pada Perusahaan Non Keuangan Yang 
Terdaftar Di Bursa Efek Indonesia Periode Tahun 2007-2009, Jurnal.

Arfan,Muhammad dan Maywidlan, Trilas, 2013, "Pengaruh Arus Kas Bebas, Collateralizable Assets, DanKebijakan Utang Terhadap Kebijakan Dividen Pada Perusahaan Yang Terdaftar Di Jakarta Islamic Index", Jurnal Telaah \& Riset Akuntansi,Vol. 6 No. 2 Juli 2013, Hlm. 194-208, Fakultas Ekonomi, Universitas Syiah Kuala .

Astuti, Sri Dewi, 2012, "Pengaruh debt to equity ratio, net profit margin, cash ratio, growth, dan size terhadap dividen payout ratio (studi kasus pada perusahaan manufaktur yang terdaftar di bursa efek indonesia tahun 2004-2010)", Skripsi, Sekolah tinggi ilmu ekonomi bank BPD jawa tengah, Semarang.

Brigham, E.F dan Houston, J.F, 2001, Manajemen keuangan, Edisi 8, Erlangga, Jakarta.

Chen, Jianguo dan Nont Dhiensiri, 2009, “ Determinants Of Dividend Policy. The Evidende of New Zealand", International Research Journal of finance and economy, Issue 34 : 18-28.

Deitiana,Tita, 2009, "Faktor-Faktor Yang Mempengaruhi Kebijakan Pembayaran Dividen Kas", Jurnal Bisnis dan Akuntansi, Vol.11, No.1, Hlm 57-64.
Djumahir, 2009, "Pengaruh Biaya Agensi, Tahap Daur Hidup Perusahaan, dan Regulasi terhadap Kebijakan Dividen pada Perusahaan Manufaktur di Bursa Efek Indonesia ", Jurnal Manajemen Dan Kewirausahaan, Vol.11, No. 2, hlm 144-153, Fakultas Ekonomi, Universitas Brawijaya Malang.

Gitman dan Lawrence J. 2003. Principles of Managerial Finance. 10th edition. Addison Wesley.

Ghozali, Imam, 2011, Aplikasi Analisis Multivariate Dengan Program Ibm Spss 19 Edisi 5, Badan Penerbit Universitas Diponogoro, Semarang.

Halim, Junaedi Jauwanto, 2013, "FaktorFaktor Yang Mempengaruhi Kebijakan Dividen Perusahaan Yang Terdaftar Di Bursa Efek Indonesia Pada Sektor Industri Barang Konsumsi Periode 20082011", Jurnal Ilmiah Mahasiswa, Vol. 2, No. 2, Hlm 1-19, Universitas Surabaya, Surabaya.

Hanafi M Mamduh, 2004, Manajemen keuangan, BPFE, Yogyakarta.

Handayani, Dyah, 2010, “Analisis FaktorFaktor Yang Mempengaruhi Dividen Payout Ratio Pada Perusahaan Manufaktur Di Bursa Efek Indonesia Periode 20052007”, Skripsi, Fakultas Ekonomi, Universitas Diponogoro, Semarang.

Hardiatmo,Budi dan Daljono, 2013, "Analisis Faktor - Faktor Yang MempengaruhiKebijakan Dividen (Studi Empiris Perusahaan Manufaktur YangListing Di Bursa Efek Indonesia Periode 2008 2010)", Diponegoro Journal Of 
Accounting, Volume 2, Nomor1, Halaman 1-13(http://ejournals1.undip.ac.id/index.php/accountin $\mathrm{g}$ diakses 6 november pukul 21.00 wib)

Haryetti dan Ekayanti, Ririn Araji, 2012, "Pengaruh Profitabilitas, Investment Opportunity Set Dan Pertumbuhan Perusahaan Terhadap Kebijakan Dividen Pada Perusahaan Lq-45 Yang Terdaftar Di Bei”, Jurnal Ekonomi Volume 20, Nomor 3 September 2012, Fakultas Ekonomi, Universitas Riau, Pekanbaru.

Hikmah, Khoirul dan Astuti, Ririn, 2013, "Growth Of Sales, Investment, Liquidity, Profitability, DanSize Of Firm Terhadap Kebijakan Dividend Payout Ratio Pada Perusahaan Manufaktur Yang Terdaftar Di Bursa Efek Indonesia", Jurnal Manajemen dan Akuntansi, Volume 2, Nomor 1, April 2013, Hlm 1-15, FE, UPN Veteran, Yogyakarta.

Husnan, Suad, 1997, Manajemen keuangan teori dan penerapan (keputusan jangka panjang), Edisi 4, Yogyakarta : UPPAMP YKPN.

Karjono, Albertus dan Rony Frans Donal Matondang, 2010, "Beberapa Faktor Yang Mempengaruhi Dividend Payout Ratio Pada Perusahaan Manufaktur Yang Terdaftar Di Bursa Efek Indonesia", Esensi, Vol.13, No.1, Institut Bisnis Nusantara, Jakarta.

Keloko, Octhara Fronimoi S., 2013, "Analisis Faktor-Faktor Yang Mempengaruhi Dividend Payout Ratio Terhadap Perusahaan Manufaktur Yang Terdaftar Di Bei”, Skripsi, Fakultas Ekonomi, Universitas Sumatera Utara
,Medan.(repository.usu.ac.id/bitstr eam/123456789/35080/4/Chapter \%20II.pdfDiakses 30 november 2014 pukul 19.42 wib)

Latiefasari,Hani Diana, 2011, "Analisis Faktor-Faktor Yang

Mempengaruhi Kebijakan Deviden(Studi Empiris Pada Perusahaan Manufaktur Yang Terdaftar Di Bei Periode 20052009)", Skripsi, Universitas Diponogoro, Semarang.

Litzenberger,Robert H. Dan Ramaswamy, Krishna, 1980, "Dividends, Short Selling Restrictions, Tax-Induced Investor Clienteles and Market Equilibrium", The Journal of Finance, Volume 35, Issue 2, pages 469-482.

Lopolusi,Ita, 2013, “Analisis FaktorFaktor Yang Mempengaruhi Kebijakan Dividen Sektor Manufaktur Yang Terdaftar Di Pt Bursa Efek Indonesia Periode 2007-2011", Jurnal Ilmiah Mahasiswa, , Vol.2, No.1, Hlm 118, Universitas Surabaya, Surabaya.

Marietta, Unzu dan Sampurno,Djoko, 2013, "Analisis Pengaruh Cash Ratio, Return On Assets, Growth, Firm Size, Debt to Equity Ratio Terhadap Dividend Payout Ratio : ( Studi Pada Perusahaan Manufaktur Yang Terdaftar di Bursa Efek Indonesia Tahun 20082011)" , Diponegoro Journal of Management, Volume 2, Nomor 3, Tahun 2013, Halaman 1-11, Fakultas Ekonomika dan Bisnis, Universitas Diponegoro, Semarang.

Marietta, Unzu ， 2013, “Analisis Pengaruh Cash Ratio, Return On Assets, Growth, Firm Size, Debt 
to Equity Ratio Terhadap Dividend Payout Ratio : ( Studi Pada Perusahaan Manufaktur Yang Terdaftar di Bursa Efek Indonesia Tahun 2008-2011)", Skripsi,Fakultas Ekonomika dan Bisnis, Universitas Diponegoro, Semarang.

Marlina, Lisa dan Danica,Clara, 2009, "Analisis Pengaruh Cash Position, Debt To Equity Ratio, Dan Return On Assets Terhadap Dividend Payout Ratio", Jurnal Manajemen Bisnis, Volume 2, Nomor 1, Januari 2009: 1 - 6 .

Megawati, Vicky, 2011, "Analisis Faktor - Faktor Yang Mempengaruhi Dividend Payout Ratio Pada Perusahaan Manufaktur Yang Terdaftar Di Bursa Efek Indonesia", Skripsi, Fakultas Ekonomi, Universitas Pembangunan Nasional "Veteran" , Yogyakarta.

Midiastuty,Pratana Puspa et al, 2014, "Analisis Kebijakan Dividen: Suatu Pengujian Dividend Signaling Theory Dan Rent Extraction Hypothesis", Fakultas Ekonomi Universitas Bengkulu. (repository.unib.ac.id/7030/1/Proc eeding\%20SNA.PDF diakses 30 november pukul $20.28 \mathrm{wib}$ )

Modigilani,F dan Miller M, 1958, The Cost Of Capital, Corporation Finance And The Theory Of Investment, American Economic Review Vol.48 No.3 http://www.Jstor.Org/Stable/1809 766 (Diakses 28 November 2014) Universitas Riau, Pekan baru.

Ndaru Sutrisno, 2010, “Analisis FaktorFaktor Yang Mempengaruhi Dividend Payout Ratio Pada Perusahaan Yang Terdaftar Di
Daftar Efek Syariah (Des) Periode 2007-2009”, Skripsi, Universitas Islam Negeri Sunan Kalijaga, Yogyakarta.

Nirwanasari, Siswi, 2007. "Pengaruh Rasio Keuangan Terhadap Dividen Payout

Ratio pada Perusahaan yang Terdaftar di Bursa Efek Jakarta 2002-2004”, Skripsi, Program studi akuntansi, Yogyakarta: Universitas Islam Indonesia. http://rac.uii.ac.id/server/documen t/Public/200904060838519931206 6.pdf (Diakses tanggal 30 November 2014 pukul $22.00 \mathrm{wib})$

Nuringsih, Kartika, 2005, “Analisis Pengaruh Kepemilikan Manajerial, Kebijakan Utang, ROA, Dan Ukuran Perusahaan Terhadap Kinerja Dividen : Studi 1995-1996", Jurnal Akuntansi dan Keuangan Indonesia, Vol.2, No.2, Universitas Tarumanegara, Jakarta.

Prasetyo, Fayakun Nur ,2012, "Analisis Pengaruh Npm, Current Ratio, Der, Company's Growth, Firm Size, Dan Collateralizable Assets Terhadap Dividend Payout Ratio Studi Empiris Pada Perusahaan Non Keuangan Yang Terdaftar Di Bursa Efek Indonesia Tahun 20072010)", Skripsi, Fakultas Ekonomika Dan Bisnis,Universitas Diponegoro, Semarang.

Pribadi, Anggit Satria dan Sampurno, Djoko , 2012, "Analisis Pengaruh Cash Position, Firm Size, Growth Opportunity, Ownership, Dan Return On Asset Terhadap Dividend Payout Ratio", Diponegoro Journal Of Management, Volume 1, Nomor 1, Halaman 212-211, Fakultas 
Ekonomika dan Bisnis, Universitas Diponegoro, Semarang.

Puspita, Fira, 2009, "Analisis FaktorFaktor YangMempengaruhi Kebijakan Dividend Payout Ratio (Studi Kasus Pada Perusahaan Yang Terdaftar Di Bursa Efek Indonesia Periode 2005-2007)", Tesis, Universitas Diponegoro, Semarang

Putra, Cendekia S, 2011, "Analisis Faktor-Faktor Yang Berpengaruh Terhadap

Dividend Payout Ratio", Jurnal, Fakultas Ekonomi, Universitas Diponegoro, Semarang.

Rahmawati, Siti Nur, 2008, "FaktorFaktor Yang Mempengaruhi Dividend Payout Ratio Studi Empiris Pada Perusahaan Yang Terdaftar Di Jakarta Islamic Index Periode 2000-2004”, Skripsi, Fakultas syariah, Universitas Islam Negeri Sunan Kalijaga, Yogyakarta.

Sant, Rajiv dan Cowan, Arnold R., 1994, "Do Dividends Signal Earnings? The

Case Of Omitted Dividends", Journal of Banking and Finance, v18 \#6, 1113-1133. (http://www.bus.iastate.edu/arnie/ OmittedDividendsPaper.pdf diakses 30 november 2014 pukul 20.52 wib)

Santoso, Habib Dwi, 2012, “Analisis Faktor-Faktor Yang Mempengaruhi Kebijakan Dividen (Studi Empiris Pada Perusahaan Manufaktur Yang Terdaftar Di Bursa Efek Indonesia Periode 2007-2009)", Skripsi, Fakultas Ekonomi Dan Bisnis Universitas Diponegoro, Semarang.
Santoso, Habib Dwi, dan Prastiwi, Andri, 2012, "Analisis Faktor-Faktor Yang Mempengaruhi Kebijakan Dividen (Studi Empiris Pada Perusahaan Manufaktur Yang Terdaftar Di Bursa Efek Indonesia Periode 2007-2009)", Diponegoro Journal Of Accounting, Volume 1, Nomor 1, Halaman 1-12., Fakultas Ekonomi Dan Bisnis Universitas Diponegoro, Semarang.

Sartono, Agus, 2001, "Kepemilikan orang dalam (insider ownership), utang, dan kebijakan dividen : pengujian empirik teori keagenan (agency theory)", Jurnal bisnis dan ekonomi, Vol.9, No.1.

Setiawan, Yudi, 2013, "Pengaruh IndependensiDewan Komisaris, Reputasi Auditor,Rasio Hutang, Dan CollateralizableAssets Terhadap Kebijakan Dividen(Studi Empiris Pada Perusahaan Manufaktur Yang TerdaftarDi Bursa Efek Indonesia Periode 2009-2011)", Skripsi, Fakultas Ekonomi, Universitas Diponegoro, Semarang.

Silitonga,Desmon 19 april 2013, Kebijakan Dividen dan Nilai Perusahaan, http://www.mdifunds.com/new/?p =461 (Diakses 6 november 2014 pukul 19.30 wib)

Sumiadji, 2011, "Analisis Variabel Keuangan Yang Mempengaruhi Kebijakan Dividen", Jurnal Dinamika Akuntansi, Vol.3, No.2, Politeknik Negeri Malang, Malang.

Susanto, yulius kurnia, 2011, "Kepemilikan saham, Kebijakan dividen, Karakteristik perusahaan, Resiko sistimatik, Set peluang 
investasi", Jurnal Bisnis Dan

Akuntansi, Vol. 13, No. 3, Hal. 195-210, STIE Trisakti.

Sugiono, 2008, Metode penelitian kuantitatif, kualitatif dan $R \& D$, CV Alfabeta, Bandung.

Taufiq, 2014, "Analisis Pengaruh Cash Position, Profitabilitas, Potensi Pertumbuhan Dan Kepemilikan Minoritas Terhadap Dividend Payout Ratio", Skripsi, Fakultas Ekonomi Dan Bisnis, Universitas Hasanuddin, Makassar.

Wahyudi, Eko dan Baidori, 2008, "Pengaruh Insider Ownership, Collateralizable Assets, Growth In Net Assets, dan Likuiditas Terhadap Kebijakan Dividen Pada Perusahaan Manufaktur Yang Listing Di Bursa Efek Indonesia Periode 2002-2006, Jurnal Aplikasi Manajemen, Vol.6, No.3.

Wahyuni,Eka Sri, 2013, "Pengaruh Profabilitas, Likuiditas, Dan Ukuran Perusahaan Pt Sepatu Bata Tbk", Skripsi, Universitas Pendidikan Indonesia (Repository.Upi.Edu Diakses 6 November 2014 pukul 19.00 wib)

Weston,Fred Dan Copeland, Thomas E. ,1997, Manajemen Keuangan Edisi Kesembilan Jilid 2, Binarupa Aksara, Jakarta (Diakses 28 November 2014) 